\title{
PATTERNS OF DEVELOPMENT OF RELATIONS OF LAND OWNERSHIP IN THE AGRARIAN SECTOR OF THE ECONOMY
}

\author{
Olga SHULGA ${ }^{1}$ \\ Kyiv National Economic University named after Vadym Hetman, Ukraine
}

\begin{abstract}
Every economic system is based on a certain system of relations of property that answers the certain level of development of productive forces. When this system of relations of property stops to provide progress of economic development, there is a necessity to substitute it by a new one. Exactly the objective necessity of development of productive forces predetermines the necessity of origin of new, higher pattern of ownership. For every system of relations of property, its own system of contradictions that provides its development is typical. Solving these contradictions conduces to the appearance of new adequate forms of further development of the system of property relations. In relation to the agrarian sector of the economy, any contradiction of agrarian relations is a form of expression of contradictions that are based on contradictions of land property relations. This implies that contradiction of relations of land ownership is the basic one in the system of agrarian relations and without its decision, it is impossible to solve all other contradictions of the agrarian sector and to form effective agrarian relations. For this reason, in order to work out an effective agrarian policy on the solution of existing in the agrarian sector contradictions, it is important to find out contradictions and law of development of land property relations in it. The topic of research is contradictions and laws of development of re land property relations in the agrarian sector of the economy. For clarifying these issues, there are applied dialectical, dynamic, systematic, and unity of logical and historical approaches, methods of generalization, analysis and synthesis, etc. The purpose of the article expose dialectics of contradictions of development of institutional public forms of the functioning of economic systems and property relations in the agrarian sector, to define laws of development of land property relations. The driving forces of the development of any economic system are contradictions between the form of land ownership and the form of land tenure, between the form of land tenure and the form of direct farming, between the owner of the land and the immediate worker on it. The dialectic of the development of institutional social forms of the functioning of economic systems and property relations in the agrarian sector is that the development of land ownership relations leads to changes and transformations in the system of production relations, their transition to a higher stage of socio-economic development, and the emergence of new social forms of functioning of economic systems. In turn, the emergence of new social forms of the functioning of economic systems causes changes in the structure of property ownership on the land, leading to the emergence and dominant position in the agricultural sector of new types and forms of ownership, reflecting the socio-economic nature of the current social system. On the basis of the analysis of the evolution of land ownership relations in various economic systems, one can conclude that their development is characterized by certain patterns: the development and complication of property patterns are constantly underway; each form of ownership by its nature is historical; the emergence of a more developed form of ownership of land does not lead to a complete disappearance of the previous form of ownership; the more specific forms of ownership within a certain mode of production, the stronger are the driving forces and sources of economic system development; as the evolution of property relations weakens the antagonistic nature of social contradictions, there is a convergence of interests of opposing classes, social groups; each functional form of ownership reflects a certain level of development of the productive power of human labour; the means of realization of any type, type or form of ownership is the degree of human freedom; the development of the essential basis of property relations takes place in an evolutionary way, and the change in the legal form of ownership - institutional instruments; institutional forms of property combine both old forms and new; each typical civilization is characterized by a predominant property object that is specific for its conditions of development, which reflects the achieved level of development of the productive labour force of man and the corresponding formative peculiarities of the appropriation of means and production results, etc.
\end{abstract}

Key words: land ownership relations, contradictions, agrarian sector, institutional social forms of functioning of economic systems, land use.

JEL Classification: Q150:O130, J100, Q100, P170:P270:P510, R140

Corresponding author:

${ }^{1}$ Department of Accounting and Audit, Faculty of Economics, Ivan Franko National University of Lviv.

E-mail: nkhocha@ukr.net 


\section{The problem and its connection with important scientific and practical tasks}

At the heart of each economic system is a certain system of property relations, which corresponds to a certain level of development of productive forces. When this system of property relations ceases to ensure the progress of economic development, there is a need to replace it with a new one. It is the objective need for the development of productive forces that necessitates the emergence of a new, higher form of ownership. Each system of property relations is characterized by its own system of contradictions, which ensures its development. The solution of these contradictions leads to the appearance of new adequate forms of further development of the system of property relations.

Regarding the agrarian sector of the economy, any contradiction in agrarian relations is a form of expression of contradictions based on conflicts of ownership relations with the land. It follows that the contradiction in land ownership relations is fundamental in the system of agrarian relations and, without it, it is impossible to resolve all other contradictions in the agricultural sector and to form effective agricultural relations. That is why, in order to develop an effective agricultural policy to resolve the contradictions existing in the agricultural sector, it is important to clarify the contradictions and patterns of development of land ownership relations.

\section{Analysis of recent publications on the problem}

Significant contributions to the study of the contradictions of social systems have made such scientists as V. M. Heyets, A. A. Gritsenko, Yu. K. Zaitsev, O. M. Moskalenko, V. S. Savchuk, V. M. Tarasevich, A. A. Chukhno and others. However, issues that are not nearly investigated are related to the identification and analysis of socio-economic contradictions in the system of agrarian relations of the modern economy, the elucidation of the laws of development of land property relations. The coverage of these issues will allow developing an effective agrarian policy, strategy, and tactics to resolve socio-economic contradictions in the system of agrarian relations.

\section{Formulation of research objectives}

The purpose of the paper is to reveal the dialectics of contradictions in the development of institutional social forms of the functioning of economic systems and property relations in the agricultural sector and to determine patterns of development of property ownership relations with the land. In clarifying these issues, there were applied dialectical, dynamic, systematic, and unity of logical and historical approaches, methods of generalization, analysis, and synthesis, etc. On the basis of the analysis of the evolution of land ownership relations in different types of economic systems, the dialectics of contradictions in the development of institutional social forms of the functioning of economic systems and property relations in the agrarian sector were revealed, and patterns of land ownership development were determined.

\section{The presentation of the main results and their justification}

The driving forces of the development of any economic system are contradictions between the form of land ownership and the form of land tenure, between the form of land tenure and the form of direct farming, between the owner of the land and the immediate worker on it. The main one is the first contradiction since ownership and ownership do not coincide. Ownership is a relationship between people about the appropriation, functioning, and alienation of life's benefits, which manifests itself through the possession, use, and disposal of property. Ownership is, as a rule, long-term use with the incomplete appropriation of material goods. That is, the owner has more rights than the owner. The second contradiction determines the economic content of specific forms of management, and the third contradiction appears in a real form in conditions where the owner and the landowner are one and the same person. In all other cases, it acts indirectly (Filonenko, 1996).

\section{Evolution of land ownership}

Depending on the historical and functional method of technological transformation of production resources into its results, there are three types of economic systems: pre-industrial, industrial, and post-industrial economic systems (Bashnyanin, 1999). Each type of economic system is characterized by a certain system of property relations, which is constantly evolving and complicated, gaining new forms of development.

In general, land ownership during the history of mankind was in its evolution, three stages (levels) of development: communal - private - social property. We follow how the development of each form of ownership took place in different types of economic systems, which causes the emergence and existence of a particular form of ownership, and which sources of development and driving forces are in each of them.

The first form of the functioning of socio-economic relations in preindustrial economic systems was the original herd whose existence was conditioned by the low level of development of productive forces. For this stage of development of society, typical were communal ownership of land and the collective organization of labour and production of members of the primitive community, based on the simple cooperation of labour using the muscular energy of people. The division of labour in the primitive herd was based on sex and age. 
An important role in the development of productive forces was played by the emergence of tools for working metal, which allowed increasing productivity of producers and led to the emergence of an additional product, which could now be assigned not only direct producers and members of their families but also other members of society. It served as the basis for the emergence of human exploitation of man, which represented the possibility of appropriating the results of the work of other people to meet their own needs. Conditions are created for the formation of a class society.

As the productive forces develop, there is a social division of labour: firstly, the tribes that were engaged in cattle breeding distinguished themselves, later the craft was separated from agriculture and animal husbandry. This has led to the emergence and expansion of an exchange not only within communities but also between communities. The exchange becomes more regular, there is money. There is a transition to the application of drag force of working animals and the use of tools of work from metal, there is a tendency to individualization of production.

It is possible to parse the ownership relations with the possession, use, and disposal of means of production, including land. Usually, the right to own land was fixed by the community, the right to use was granted to individual families, and the right to dispose of the family. In parallel, this is the birth of private ownership of the means of production. In turn, the development of commodity-money relations leads to the expansion of the primitive communal system, the existence of which was conditioned by the need for a social association of people in order to secure a minimum of livelihoods.

In place of the original system, the slave system, the material basis of which was the servile work of slaves on the basis of cooperation, comes. The slave system was based on the property of the slaveholders on the means of production, the main productive force - the slave and the product created by slaves. Slaves who worked on large slave farms, the so-called latifundia, were not, on the basis of direct coercion, interested in improving the productivity of their labour. However, for some time, the organization of management on the basis of cooperation of the work of slaves allowed creating a product sufficient not only to meet the needs of the slave and the half-starved existence of slaves but also for the market implementation. Despite this, slave farms were mostly natural.

Along with the large slave farms in agriculture, there were small farms of free peasants, whose production took place in order to meet public needs. Their existence was conditioned by the need to preserve the peasant as a warrior and taxpayer, on which the economic, political, and military power of the state depended. Free peasants, unlike slaves, were interested in increasing production volumes and improving the quality of their products.
However, the low level of development of labour tools caused the low productivity of their labour, resulting in their inferiority to the great slave farms, in which the growth of agricultural production was due to low costs for the maintenance of slaves and the use of the effect of concentration of land and the cooperation of the work of slaves. As a result, small owners were blown up and either got into slavery or went to the city, becoming a pauper or a retinue of senators and rich people.

However, over time, dissatisfaction amongst the slaves increased, they began to break the tools, to rise, and the slaveholdings, in turn, began to decline. This was manifested in reducing the area of cultivated land, the spread of extensive forms of farming, etc. It became clear that the technical capabilities of the slave management of the economy were exhausted. Slaves were not interested in improving the tools of labour, and free people increasingly preferred classroom philosophy, politics.

The contradiction between large farms of slave owners and farms of free small producers has become sharpened. For slave owners, the obvious need was to find ways to increase the interest of slaves in the effective use of tools and improve the results of their work. There was a need to change the form of a combination of a direct manufacturer with means of production. A bet was made to strengthen small individual farms, which were in terms of motivation to work more rational forms of farming but with the preservation of large land tenure. Changes in the organization of production in latifundia begin, which begin to be divided into small plots, so-called parcels, rented to small peasants (columns). As a result, the latter, remaining free people fell into a land dependence on the landowner by agreement, which was liquidated at the request of one of the parties.

As for slaves, slave-owners began to expand their economic independence, giving slaves land and turning them into dependent colonate type. Distributing rental relations in the form of cash and cash payments, as well as outsourcing. Thus, the development of the slave system was by way of self-denial of communal property, displacement of its individual form of private property. That is, private property becomes an expression of the transformation of social labour into private labour, isolated commodity producers. Now the subject of ownership is not the community as a whole but a separate person.

Formation of the class of individual owners created the preconditions for the transition to a feudal system, which was called to resolve the contradictions of the slave system. For feudalism, there were three main forms of land tenure: 1) state land ownership of the crown, which remained in the hands of the state after the distribution of land privileged classes; 2) a large private land ownership of feudal lords, landlords and 3) small peasant ownership with the preservation of remnants of communal forms of land tenure. By the end 
of the nineteenth century, the private property of the privileged classes and peasant ownership were burdened with legal, economic, and statutory restrictions on the purchase, distribution, inheritance of land, etc.

Feudal production relations were based on the individual dependence of peasants from feudal lords on the basis of non-economic coercion. However, they differed from similar relations in the era of the slave system, because to some extent contributed to the peasants' interest in the results of their work. On the one hand, they did not stimulate dependent peasants to improve the results of their labour on the feudal livelihood but, on the other hand, they stimulated them to improve the results of their labour on the land they gave to the exploitation of the feudal lord and on which their farming the purpose of meeting the needs of the family in food and reproducing their own means of production, which they used in their own economy, and in the economy of the feudal lord. In addition, unlike slaves, dependent peasants had their own housing and economic buildings, and the possibility of using some of the lands owned by the rural community (despite its subordination to the feudal lord).

Feudal production was carried out in two forms - in the form of a bastard and in the form of obsolete households. In the battleship, the whole land of the feudal estate was divided into two parts: one - the mansion, on which the peasant, with his labour and inventory, created a product that was fully attributed to the feudal lord, and the second was a peasant subdivision, on which the peasantry was created, the product was completely aimed at satisfying needs of the family and play his inventory. In the abandonment of land, almost all the land was transferred to the peasants and was in their abode. The part of the peasants' products created in the farms was transmitted in the form of a feudal lord, and a part of it was left by the peasant to satisfy the food needs of his family and the reproduction of the inventory. Thus, in the conditions of the barter, additional work is carried out forcefully and assigned in the form of working rent, and in the conditions of the obrok system - voluntarily, without coercion and supervision, and is assigned in the form of food rents (Chukhno, 2006).

As a result of the greater interest of dependent peasants in the results of their work for feudalism, there was a certain development of productive forces that predetermined the development of commodity production and commodity exchange, which in turn led to the formation of the domestic market, the strengthening of trade relations between the city and the village, activation of foreign trade. The feudal economy was increasingly drawn into commoditymoney relations, its closure, and isolation from peasant farms. This led to the transfer of peasants from work and product rents to cash. Monetary rent showed a higher level of development of agrarian relations because now the peasant should not only grow the produce but also realize it on the market. In addition, his position changed, it approached the position of the employertenant. Thus, the feudal system, albeit characterized by a simple reproduction, but was more progressive in comparison with the slave-owner. He expanded the economic independence of direct producers and brought them closer to the ground, contributing to the greater motivation of their work.

Under the conditions of further development of commodity-money relations, there was an intensification of the exploitation of the dependent peasantry by the feudal lords. As a result, this negatively affected both the state of affairs in the farms of feudal lords, as well as in the farms of peasants. Some peasants who were left without land were forced to go to the city or work in farms rich in peasants, turning into hired workers. This has led to an increase in property and social inequality in the countryside.

Feudal relations prevented the transition of agriculture to a new mode of production, which required a large number of free hired workers. Accordingly, the natural nature of feudal and peasant farms was incompatible with the needs of further economic development, which required new forms of organization of production and labour, a new way of combining direct producers with means of production, overcoming their personal dependence on feudal lords, that is, the replacement of feudal industrial relations with new ones, which would contribute to the development of productive forces and meet the needs for further economic development (Chukhno, 2006).

Thus, as we see, industrial relations in pre-industrial economic systems were based on communal and private non-capitalist property of the means of production. However, the first emerged communal ownership of land. Objective reasons for its occurrence and existence were: 1) the emergence of agriculture as an industry, which largely depended on the satisfaction of food in need; 2) the low level of development of productive forces, in which separate individual farming was practically impossible; 3) a low level of production, in which the necessary product for the existence could be created only by joint efforts of members of the community on the basis of the cooperation of their work, etc. (Filonenko, 1996).

The peculiarity of communal appropriation of land was that people perceived it as given to them by nature, and land ownership actually coincided with land tenure. However, with the transition from the primitive community to the rural (neighbouring), the allocation of a family of general tribal community and the separation of ownership of land from actual land tenure took place. The consequence of this was the emergence of a rural community, the classical form of which was the so-called mark that existed in Germany, England, and some other countries. The peculiarity of the brand, inherent in other forms of rural communities, is the separation of land ownership of the family. In parallel, 
there is the emergence of private ownership of the land, on which the house was built.

According to the village community, each member of the family received a certain portion of the so-called Gufa for use, all the land was considered to be the property of the community. Scientists assume that at first the sizes of the Guf were the same, and communal ownership extended to all types of land. But subsequently, as a result of periodic redistribution of land allotments, the tendency towards the unequal distribution of members of the community began to emerge, and communal use of land spread only to some areas.

Over time, the community under the pressure of its individual members abandoned the right to periodically redistribute arable land and meadows. However, it did not retreat from all other rights. First, the community transferred its lands to individual families and individuals only for the purpose of their use as arable land or meadows; and secondly, the treasures found in the land, the fossils that lay deeper than the demarcation, belonged to the community; Thirdly, all another land that was not a part of the estate, and the arable land (forests, pastures, ponds, hunting, and fishing) remained communal property, and were put into public use, the manner of which was determined jointly by all members of the community; Fourth, the community retained the right to control and regulate the use of field lands and meadows (Filonenko, 1996).

Thus, as we see, the foundations of land inequality and the possibility of developing private property on land were laid in the neighbouring community. With the development of large private land tenure community begins to die, and with it disappear also communal forms of land use because of the seizure of communal lands by large landowners. Instead, the peasantry, having become dependent on the latter, is transformed from former independent landowners into dependent tenants.

However, even after the seizure of communal lands by large landowners and the spread of serfdom to peasants, communal land use continued to persist for a long time, reaching more advanced forms. Dependent peasants continued to use communal lands for a long time on the basis of a "fate" or "bastard" community, and with the abolition of serfdom retained their holdings on the basis of private labour property. However, the remnants of communal land use and communal practices are now found in many countries of the world in the form of mussels, communal use of land of mountain pastures, forests and other lands.

The agricultural community was a transitional phase to a private property-based society. It should be noted that private ownership of land is a reflection of conditions of land use in the process of formation and development of commodity-money relations. It occurs when an additional product appears in agriculture and when it comes to the possibility of appropriating money for production, in particular land.
The feudal relations ensured the initial accumulation of capital, without which capitalism could not be established, which, as a social mode of production, is inherent in industrial economic systems. The driving force that transforms preindustrial economics into industrial is the process of industrialization, that is, the transition of national economies to production based on the use of machines and machinery.

It is in the process of initial accumulation of capital and, as a result of the development of the previous mode of production, there is a capitalist system, which was based on the private property of the capitalists on the means of production and the economic (real) dependence of legally free workers from the owners of capital, which, due to the lack of them means of production and livelihoods, are forced to sell to the capitalists their workforce. Under capitalism, the destruction of the natural economy and the development of capitalist commodity production; the purpose of production is to become profitable and meet the needs of society; labour is transformed into goods along with other means of production; there is an unprecedented development of productive forces, which is accompanied by constant scientific and technological progress in the field of technology, technology, organization of agricultural production and labour, etc. Thus, capitalism has generated economic incentives that have contributed to the scientific and technological progress and the interest of producers in implementing its achievements in production.

At first, the capitalist economy was based on the simple co-operation of the work of hired workers, which, ensuring higher productivity of workers compared with the feudal system, eventually allowed to go to the manufactory, and after the industrial revolution of the late XVIII -early XIX century - to a large machine production, the form of organization, which was the factory. The capitalist organization of labour led to the emergence of a new productive force - the machines that led to the intensification of the work of hired workers, the intensification of their exploitation. The form of exploitation of hired workers is now supported by their added value, which the capitalist appropriates according to the size of the capital invested.

The development of capitalism is accompanied by the mass seizure of property from small producers, the deepening of property and social differentiation in society, the change in the social status of the majority of people who have turned into hired workers and became dependent on the owners of capital, the formation of the labour market, the initial accumulation of capital, etc. As a result of these processes, on the one hand, is the enrichment of the capitalists, and, on the other hand, the impoverishment of hired workers. This is precisely the contradictory nature of the capitalist society, the basis of which is the contradiction between the general logic of historical progress (the latter is the subordination of 
the production of human development) and the goal of industrial development.

With the growth of production and accumulation of capital began to intensify the processes of concentration and centralization of capital and production, the trend of monopolization. This created conditions for the expansion of a new form of organization of production and labour, which is corporations, and the growth of the role of corporate property, which is realized simultaneously as an individual capitalist private, collective capitalist private and as labour private property. The proliferation of corporate property led to qualitative changes in the interaction of business entities through the convergence of interests of entrepreneurs, hired workers and the state, the development of a partnership between the state and business, social responsibility of business, etc. At the same time, a decrease in the value of individual capitalist property began to be observed.

However, after the scientific and technological revolution of the second half of the twentieth century, the situation has changed: medium and small enterprises, which, due to high specialization and mobility, are achieving higher results and higher efficiency compared to large enterprises, they began to grow. The latest scientific and technological revolution has accelerated the changes in the development of the capitalist system, led to the emergence of new trends and patterns. On the one hand, in the conditions of intensification of processes of concentration and centralization of capital, integration, and internationalization of production, there is the existence of large corporations; on the other hand, there is an increase in the number of medium and small enterprises, and the strengthening of competition between them (Chukhno, 2006). That is, processes of integration of labour and production, diversification and deconcentration of production, demonopolization and decentralization of production and management, and capitalization processes are supplemented by the processes of socialization; private property acquires forms of collective-private, joint-stock, corporate, etc. Appearing intellectual property and spreading its various forms - personal, individual private, collective, corporate, state property. In addition, there are new forms of relations between economic entities (for example, the system of joint ownership of intellectual capital by all investors).

Under these conditions, a transition to a new technological mode of production is taking place, where knowledge and information become the main sources of economic growth. The role of the service sector, which provides training for highly skilled workers, is growing, while the scope of material production is narrowing. There is an increase in the proportion of mental labour. Accordingly, the role of living, highly skilled labour, the intellectualization of the worker and the socialization of conditions of his work and life, the priority for wage workers become a satisfaction of spiritual needs, and the source of satisfaction of these needs is the social benefits, not just wages. This means that, unlike the previous stages of the development of a capitalist society, which was based on private property and solved private tasks, nowadays, state property and social (social) forms develop alongside it. Capitalist society enters the post-industrial era (Chukhno, 2006).

It should be noted that the mass transition to machinebuilding in the agrarian sector took place later than in the industry. This was mainly due to the coexistence of various forms of ownership in the agrarian sector, inherited from different economic systems, and the lack of sufficient capital from agricultural producers. The massive activization of the processes of industrialization of the agrarian sector in developed countries of the world has been manifested in:

- wide complex application of machines and mechanical equipment for the production in all branches of agriculture, which transformed them into one of the organizational forms of industrial production;

- the rapid growth of labour productivity;

- a significant increase in the concentration and specialization of production, the emergence of new forms of agricultural enterprises similar to those operating in the industry;

- rapid concentration of capital operating in the agrarian sector;

- rapid and substantial reduction in the number of family farms; at the same time, modern forms of the functioning of private and collective property characteristic of industry (joint-stock, cooperative, collective, but with the domination of private capitalist property) became widespread;

- strengthening the processes of integration of agriculture with industrial and financial capital, etc. (Zaitsev, Savchuk, 2011).

As the analysis of the essence and laws of development of the transformation of the economic system of an industrial type and external factors of its development, it is characterized by openness, nonlinearity, flexibility, the ability to respond to changes in the needs of man and society. It is these particularities, according to Yu. K. Zaitsev and V. S. Savchuk, that allowed the capitalist society to respond in a timely manner to the rapid growth of uncompensated environmental disturbances. Such a course of transformation shows that the capitalist system has powerful motivational levers that provide sustainability and opportunities for the further development of its economic and social system, as well as the real possibilities for the dynamic functioning of individual stages of the life cycle of economic systems over a long period of time (Zaitsev, Savchuk, 2011).

In the opinion of L. A. Griffen, it was socialism that created opportunities for the further development of capitalism, which is aimed only at violence, exploitation. The existence of socialism has enabled 
the workers of the capitalist countries to succeed in meeting their demands; contributed to the collapse of the colonial system; forced the capitalist states to intensify integration tendencies in the face of the threat of destruction of the class of the bourgeoisie. However, capitalism has changed more in form than in essence. It continues to strive to exploit others, but now on a global scale, through the exploitation of natural resources and the population of developing countries. For example, the US, which has only $5 \%$ of the world's population, consumes $25 \%$ of all energy produced and $40 \%$ of natural resources (Griffen, 1994).

As we see from the foregoing, private capitalist ownership of means of production, including land, is characteristic of market-based economic systems of industrial and post-industrial type. It was historically formed in several ways: the seizure of communal lands; redemption of lands belonging to monarchs or tribal leaders; purchase of land belonging to isolated farmers; seizure of land both in conquered territories and among peasants who were the independent economy.

The emergence of private ownership of land was conditioned by the need to develop and use public division of labour. The benefits of private property were due to the fact that it contributed to the redistribution of land in accordance with the needs of social development; optimizing the sizes of farms in accordance with the technical and economic conditions and, therefore, the more effective use of land and technology on the basis of large agricultural enterprises; it created certain conditions for the formation of farms of independent landowners and encouraged them to manifest an economic initiative; land purchase and sale have made it possible to determine the economic value of land.

The sooner penetration of market relations into agriculture occurred, the sooner the old forms of feudal land relations were replaced, replaced by new, capitalist ones. However, the complete disappearance of feudal forms of land relations did not take place, therefore today in the Western European capitalist countries, there are several ways of development of land relations, among which:

1) English type of land relations, which has developed directly from feudal land ownership and is characterized by concentration of land ownership, the entire separation of land ownership from agriculture and the lack of small land ownership;

2) Prussian type of land relations, which also evolved from feudal land ownership with the preservation of latifundia in the hands of landowners. In this type of land relations take place as a large land ownership of large farms, and the small property of the peasants, but neither with it nor with another, there is no separation of land ownership from the agricultural economy;

3) French type of land relations, which preserved a number of historical remnants of feudalism and characterized by the spread of the former feudal latifundia of small land ownership of the peasant or parcel type;

4) North American type of land relations, formed on the basis of the seizure of land and their surplus in the conditions of rapid development of agricultural capitalism (Lyashenko, 1930).

Thus, on the basis of the collapse of feudal farms, based on the feudal form of private ownership of land, there were two types of farms: capitalist-entrepreneurial and peasant. The basis of peasant farms is peasant private ownership of land. Peasant ownership of land means consolidating the ownership of those who work on it; the limitedness of its economic and economic capacities associated with the work of the peasant; its dependence on forms of management, which exist on the basis of a large ownership of land.

The basis of the emergence of the capitalistentrepreneurial form of land ownership is the transformation of a large feudal property, the subjects of which are the owner of the land, the entrepreneur, the tenant and the hired worker who got rid of the land. Under conditions when the landowner is not its immediate owner, he acts as a landlord and receives rent from tenants. With regard to the tenant entrepreneur who acts on the ground and does not own the land, he provides with his own capital the creation of opportunities for the emergence of additional value, some of which later will be assigned to the owner of the land.

By destroying the old forms of great feudal land tenure and replacing them with new forms of great capitalist land tenure, the market economy system of industrial and post-industrial type did not lead either to the complete elimination of smallholders or to the full socialization and concentration of agricultural land, as was the case in industry. As a result, along with the remnants of collective communal land tenure and large private land ownership of the era of feudalism, in the agriculture of developed countries, small land tenure of the peasant type and various forms of partial land ownership of the urban population, which in economic terms are eliminated from the forms of small-scale farming, have become widespread, for housekeeping and groceries to meet the needs of the family.

The development of parcel land tenure takes place in two directions: on the one hand, in the form of the development of parcel peasant land tenure in general, when former independent peasant farms turn into parcel areas, suitable only as a mansion and a city. On the other hand - in the form of the distribution of the same parcel around cities and large industrial centres, when small areas are used by city residents as a place to rest like a city and other. Revenue from such areas does not play any significant significance at all.

From the foregoing, it is clear that the market economy system in general and in particular the capitalization of agriculture does not always lead to the concentration of land ownership. In some circumstances, the process 
of capitalization of agriculture is accompanied by a concentration of land ownership and the presence of large sizes of farms, in the opposite case, the fragmentation of land ownership, and the presence of small sizes of land holdings.

The problem of land ownership in a capitalist economy is to overcome the monopoly of land ownership, which at a certain stage becomes an obstacle to the further development of capitalist agricultural production. The negative consequence of land ownership and its rental monopoly is the impact on the development of productive forces in agriculture. The distraction of capital for the purchase of land, which leads to a reduction in investments in its cultivation, and the transition to the cultivation of the worst land these are the main negatives of land ownership for the development of productive forces and agricultural capitalization. That is, in the agricultural sector, the principle of private property conflicts with other basic principles of capitalism - economic freedom, competition, concentration trends, and socialization. The contradictions between private property and all capitalism do not disappear, even at the high stages of the capitalist process of socialization.

The historical mission of the development of capitalism in agriculture was the expansion of the feudal forms of land ownership that it inherited from the previous period and the promotion of a new form of ownership that corresponded to the level of development of productive forces and corresponded to a new mode of production. Capitalism, on the one hand, provided employees with personal independence from feudal lords, landlords, and, on the other hand, led to the separation of land from its owner, for whom land now increasingly becomes not the object of capital investment in agricultural production but a source of rental income from ownership to land. Land ownership takes on an economic form, turning into an ordinary commodity that is in demand by capitalists and tenants. This form of separation of land from agricultural production is an obstacle to its development and capitalization.

Another way to overcome the feudal forms of landed property by capitalism is to mobilize land in connection with the growth of mortgage land debt, in which capitalization of rents takes the form of mortgage debt. But if through the mobilization and price of land, capitalism adapts land, as a means of production, to the conditions of capitalist production, then mortgage debt leads to the degeneration of the very nature of land ownership and landowner. It is a question of the fact that obtaining a rent goes not to the landowner but to the bank capital. Under such conditions, the landowner turns into an agricultural producer or leaves the capitalist land relations.

A complete separation of land tenure from agriculture is through a lease. This is due to the fact that the development of lease relations, on the one hand, involves the presence of tenant entrepreneurs and hired workers, and, on the other hand, the isolation and preservation of the class of landowners. In this regard, the lease may, in some cases, be based not only on capitalist relations but also on the remnants of pre-capitalist relations and forms. Accordingly, there are two types of lease: capitalist and non-capitalist.

The capitalist lease implies the existence of developed capitalist relations in agriculture, namely: the leasing of land for the purpose of its further exploitation through the use of capital and hired labour in conjunction with the work of family members. The central figure of such a lease is the entrepreneur-tenant, who conducts commodity capitalist production. The non-capitalist lease implies the existence of undeveloped capitalist relations in agriculture and the leasing of land not so much for the purpose of its capitalist exploitation as for the purpose or satisfaction of the food needs of the family, or for the purpose of simple commodity production. The central figure of such a lease is a small producer, a peasant who leads a household to meet their food needs or to market products. Despite the prevalence of both types of the lease in different countries, there is a tendency to replace the forms of land relations of the pre-capitalist economy with forms of the capitalist lease.

As we see, the development of private ownership of land is an objective process, due to a certain system of contradictions and the need for their solution. The most important of these are:

- the possibility of separating property rights, which is a source of non-profit income, from actual land use, which leads to inefficient use of land;

- the contradiction between the interests of society in using land and the interests of the landowner;

- the contradiction between the distribution of land, caused by the ownership relations with it, and the needs of its new distribution and redistribution, caused by the development of productive forces;

- the contradiction between the market and the naturalproduction criteria of the use of land as an expression of contradictions between different methods of management (Filonenko, 1996).

The above contradictions require the search for solutions. There are three ways of resolving conflicts of private ownership of land in the agrarian sector: nationalization of land and its rents, the creation of collective agricultural enterprises, and the establishment of control by society for the use of land. The first two ways have been realized at the beginning of the last century in post-socialist countries, whose economic relations were based on the social ownership of the means of production, the social forms of organization of production and labour, the direct combination of producers with means of production, the lack of human exploitation, the systematic and proportional development of the economy, ensuring 
the comprehensive development of personality and full satisfaction of its needs. In fact, public property has been secreted. Under such conditions, direct producers were formal owners, alienated from the means of production and its results, and the removal from management thereof. This undermined their interest in the results of their work.

In addition, production under socialism was carried out in accordance with the policy plans, the implementation of which did not contribute to the implementation of scientific and technological progress in agriculture. Instead of democratizing public life, its bureaucratization took place, which limited the economic independence of labour collectives. All this led to the development of agriculture on an extensive basis. When the opportunities for such a development were exhausted, the growth rate of production began to fall, and social tension in society would increase. This conditioned the need for a radical restructuring of the system of agrarian relations and, above all, relations of ownership of land.

The situation in the agrarian sector was associated with an escalation of supremacy between the form of ownership of land and the forms of real land tenure. The impression was that the associated producers are formal owners, and the land, in essence, is a draw. In this regard, the main link of a radical restructuring of agrarian relations was to resolve this contradiction. However, unfortunately, all the efforts of the reformers focused on the restructuring of land ownership. It was not taken into account that the restructuring of land ownership relations in conditions of the ineffectiveness of public ownership of land should take place not only as a substitute for private property but also through changes and changes in the economic situation of all subjects of agrarian relations - both the owner and employee.

Thus, in the absence of proper conditions for solving this contradiction, there was a dialectical denial of public ownership and the revival of private ownership of land. In resolving the contradiction of private ownership of socialism was not taken into account: first, that the form of ownership of land is conditioned by the needs of the development of productive forces, and secondly, that the socialization of the land should correspond to the economic interests of the peasants, that is, those who will handle it.

The world experience of the restructuring of agrarian relations shows that, firstly, it is not possible to hurry to change the forms of ownership of land, and secondly, such a change should occur along with similar changes in the economy, which makes the transition to new forms of ownership of land more efficient, thirdly, the use of public property and public ownership of land is justified only when they represent one of the prerequisites for resolving the contradiction between the form of ownership of land and the forms of real use of land, etc.
Today, in developed countries, the resolution of conflicts of private ownership of land takes place by establishing control by the society for the use of land and compliance with the terms of its sale. Currently, in all countries, the land legislation provides for the state control over compliance with these conditions.

In general, it must be said that the nationalization of land, although in practice, is socially inaccessible to industrial and post-industrial societies, remaining a utopia of social transformation, but its implementation would bring a number of benefits for the development of agriculture since it would free capitalists from the need for unproductive costs for the purchase of land, created would be favourable conditions for the competition of capital in agricultural production, would lead to the disappearance of an absolute and monopoly land rent that, in its own would lead to lower prices for agricultural products, reducing the capitalist costs of production.

Thus, the dialectic of the development of institutional social forms of functioning of economic systems and property relations in the agrarian sector is that the development of land ownership relations leads to changes and transformations in the system of industrial relations, their transition to the higher stage of socioeconomic development and the emergence of new social forms of functioning of economic systems. In turn, the emergence of new social forms of the functioning of economic systems causes changes in the structure of relations of ownership of land, leading to the emergence and dominant position in the agrarian sector of new types and forms of ownership, reflecting the socioeconomic nature of the prevailing social system.

Thus, in pre-industrial economic systems, which characterized the low level of development of productive forces, social forms of organization of production and labour were largely dependent on nature and demanded the unification of people into groups in order to meet their needs and needs of the ruling class. Under such conditions, the main productive force was a man. In such systems, conditions are created for the exploitation of man by man, new social institutions arise - classes that act as production units that determine the relationship between people in the production process.

For market economical systems of an industrial type characterized by a high level of development of productive forces; preserving the division of society into social classes; the economic dependence of legally free employees from the owners of capital, which forces employees to alienate their workforce in order to secure livelihoods for themselves and their families; replacement of private non-capitalist ownership of private capitalist property (corporate, corporate, monopoly, oligopolistic); the main productive force is the machine, the person becomes an appendage to the car; capital and labour are parties to capitalist production relations; strengthening the processes of specialization and concentration of labour 
and production, centralization of ownership and management, capitalization and monopolization of production.

In a market-based economic system of postindustrial type, there is a transition to automated production; science becomes the main productive force, and important resources are knowledge and information; denied the relationship of personal and economic dependence of man; preconditions are created for ensuring the comprehensive development of the individual and the harmonious combination of the individual with the environment; processes of integration of labour and production, diversification, and deconcentration of production, demonopolization and decentralization of production and management are taking place, and capitalization processes are complemented by socialization processes; private property acquires forms of collective-private, jointstock, corporate; intellectual property appears.

If in pre-industrial systems, the main means of agricultural production growth was agricultural capital, industrial - industrial capital, then in the post-industrial information and knowledge of direct producers.

Patterns of development of relations of land ownership

In addition, on the basis of the analysis of the evolution of land ownership relations in different economic systems, one can conclude that their development is characterized by certain patterns:

1) development and complication of forms of property is constantly underway;

2) each form of ownership by its nature is historical, that is, having arisen as a result of certain circumstances, it with the termination of their actions should be replaced by another, more adequate to the new conditions. Conservation of the development of functional forms of property leads to stagnant phenomena, inhibition of social processes;

3) the emergence of a more developed form of ownership of land does not lead to the complete disappearance of the previous form of ownership;

4) the more specific forms of ownership within a certain mode of production, the stronger are the driving forces and sources of economic system development;

5 ) as the evolution of property relations weakens the antagonistic nature of social contradictions, there is a convergence of interests of opposing classes, social groups. Indeed, preindustrial economic systems were based initially on the property of the ruling class on the means of production and the employee (producer), and later on the results of his work; industrial economic systems - only on the property of the capitalist on the means of production, and post-industrial systems - on the property of the workers themselves for their unique abilities (a combination of capital and labour is in place), the social status of man is now largely determined by the level of education;

6) development of property relations has an interesting trend - in the early stages of its development, humanity used common, collective forms of ownership, then, with the development of productive forces, communal property self-denied and displaced by private property, self-development, which takes place in the direction of its socialization (socialization of the nature of labour and production) and the emergence of group and collective forms of private property;

7) each functional form of ownership reflects a certain level of development of the productive power of human labour (but this provision should not be absolutised, as the reasons that determine the logic of property relations at a certain stage of historical development are multidimensional). Type and form of ownership should correspond to the level of development and the mode of functioning of the productive forces;

8) a measure of the realization of any type or form of ownership is the degree of human freedom, that is, the form of ownership expresses the degree of freedom of action of man (from full freedom to individual production to its "restriction" by defining the framework of collective or social interests);

9) development of the essential basis of property relations takes place in an evolutionary way, and the change of legal form of ownership - institutional instruments;

10) institutional forms of ownership combine both old forms and new ones;

11) each typical civilization is characterized by a specific for the conditions of its development, the dominant object of property, which reflects the achieved level of development of the productive power of human labour and the corresponding formative peculiarities of the appropriation of means and outputs.

Thus, in agrarian civilization, the dominant object of the property was land, which, due to the development of the productive power of human labour, gradually evolved from the collective form of human existence into a separate means of its production activity. In the period of development of industrial civilization, the dominant object of the property was created by a man of the instrument of production, and the need for high concentration of them created the gap between labour and property. As a result, means of production, alienated from the workforce, have become capital forms, and labour is the form of commodity. Fundamentally new processes in property relations appear with the emergence of post-industrial civilization. Here, the main object of property is the information and knowledge that embodies the costs of the intellectual workforce, which, unlike the workforce used in traditional branches of the economy, loses the ability to alienate from its carrier. In addition, materially-conceived means of production in the process of their productive use of human labour acquire qualitatively new social features and turn into a productive force of its labour, a specific object of its individual, personalized property.

Thus, as we can see, throughout the history of mankind, the development of land ownership relations is closely associated with changes in the institutional 
forms of social functioning of economic systems. Thus, in pre-industrial economic systems, communal property, exploitative types of private property and state ownership, such as the property of kings, feudal lords and other rulers, took place. In market economical systems of industrial and post-industrial type, along with the state form of ownership, group and collective forms of private property arise and develop. That is, the self-development of private property takes place in the direction of its socialization through the transformation of a single form of capitalist private property into its corporate form.

\section{Conclusions and prospects for further research}

The dialectic of the development of institutional social forms of the functioning of economic systems and property relations in the agrarian sector is that the development of land ownership relations leads to changes and transformations in the system of production relations, their transition to a higher stage of socio-economic development, and the emergence of new social forms of functioning of economic systems. In turn, the emergence of new social forms of the functioning of economic systems causes changes in the structure of relations of ownership of land, leading to the emergence and dominant position in the agrarian sector of new types and forms of ownership, reflecting the socio-economic nature of the prevailing social system.

On the basis of the analysis of the evolution of land ownership relations in various economic systems, one can conclude that their development is characterized by certain patterns: the development and complication of property patterns are constantly underway; each form of ownership by its nature is historical, that is, arising from the action of certain circumstances, it with the termination of their actions should be replaced by another, more adequate to the new conditions; the emergence of a more developed form of ownership of land does not lead to the complete disappearance of the previous form of ownership; the more specific forms of ownership within a certain mode of production, the stronger are the driving forces and sources of economic system development; as the evolution of property relations weakens the antagonistic nature of social contradictions, there is a convergence of interests of opposing classes, social groups; each functional form of ownership reflects a certain level of development of the productive power of human labour; the means of realization of any type or form of ownership is the degree of human freedom; the development of the essential basis of property relations takes place in an evolutionary way, and the change in the legal form of ownership - institutional instruments; institutional forms of property combine both old and new forms; each typical civilization is characterized by a dominant property object that is specific for the conditions of its development, which reflects the achieved level of development of the productive labour force of man and the corresponding formative peculiarities of the appropriation of means and production results. Further research will be devoted to the development of a model of the economic policy of the state in solving socioeconomic contradictions in the agrarian sector of the modern economy.

\section{References:}

Bashnyanin, G. I., Kopych, I. M., Shevchyk, B. M. (1999). Economic systems: problems of structuring and typology. - Lviv, Co-education, 220 p.

Griffin, L. A. (1994). Dialectics of social development (the experience of modern Marxism). second edition. Kiev, Naukova Dumka, 116 p.

Zaitsev, Yu. K., Savchuk, V. S. (2011). Modern political economy (problems and institutional field of the subject and research methodology). - Kyiv, KNEU, 337, [3] p.

Lyashchenko, P. I. (1930). The main elements of the social economy of agriculture. - Moscow, $400 \mathrm{p}$.

Filonenko, O. S. (1996). Agrarian relations: content, development, future. - Kyiv, Vintage, 208 p.

Chukhno, A. A. (2006). Works: In 3 volumes. Vol. 2. Information Post-industrial Economics: Theory and Practice. Kyiv, 512 p.

\section{Ольга ШУЛьГА}

\section{ЗАКОНОМЕРНОСТИ РАЗВИТИЯ ОТНОШЕНИЙ СОБСТВЕННОСТИ НА ЗЕМЛЮ В АГРАРНОМ СЕКТОРЕ ЭКОНОМИКИ}

Аннотация. В основе каждой экономической системы лежит определенная система отношений собственности, соответствующая определенному уровню развития производительных сил. Когда эта система отношений собственности перестает обеспечивать прогресс экономического развития, возникает необходимость ее замены на новую. Именно объективная потребность развития производительных сил предопределяет необходимость возникновения новой, высшей формы собственности. Для каждой системы отношений собственности характерна своя система противоречий, которая обеспечивает ее развитие. 
Решение этих противоречий ведет к появлению новых адекватных форм дальнейшего развития системы отношений собственности. Относительно аграрного сектора экономики, то любое противоречие аграрных отношений является формой выражения противоречий, основанных на противоречиях отношений собственности на землю. Отсюда следует, что противоречие отношений собственности на землю является основным в системе аграрных отношений и без его разрешения невозможно разрешить все остальные противоречия аграрного сектора и сформировать эффективные аграрные отношения. Именно поэтому, чтобы разработать эффективную аграрную политику по решению существующих в аграрном секторе противоречий, важно выяснить противоречия и закономерности развития в нем отношений собственности на землю. Предмет исследования - противоречия и закономерности развития отношений собственности на землю в аграрном секторе экономики. Для выяснения и раскрытия этих вопросов были применены диалектический, динамичный, системный, единства логического и исторического подходы, методы обобщения, анализа и синтеза и др. Цель статьи - раскрыть диалектику противоречий развития институциональных общественных форм функционирования экономических систем и отношений собственности в аграрном секторе, определить закономерности развития отношений собственности на землю. Движущими силами развития любой экономической системы является противоречие между формой земельной собственности и формой землевладения, между формой землевладения и формой непосредственной работы на земле, между владельцем земли и непосредственным работником на ней. Диалектика развития институциональных общественных форм функционирования экономических систем и отношений собственности в аграрном секторе заключается в том, что развитие отношений собственности на землю ведет к изменениям и преобразованиям в системе производственных отношений, их перехода к высшей стадии общественноэкономического развития и появления новых общественных форм функционирования экономических систем. В свою очередь, появление новых общественных форм функционирования экономических систем обусловливает изменения в структуре отношений собственности на землю, ведет к появлению и господствующему положению в аграрном секторе новых видов и форм собственности, отражая социальноэкономическую природу общественного строя. На основе анализа эволюции отношений собственности на землю в разных экономических системах можно сделать вывод, что для их развития характерны определенные закономерности: постоянно происходит развитие и усложнение форм собственности; каждая форма собственности по своей природе является исторической; чем больше конкретных форм собственности в пределах определенного способа производства, тем сильнее являются движущие силы и источники развития экономической системы; по мере эволюции отношений собственности ослабляется антагонистическийхарактерсоциальныхпротиворечий, происходитсближениеинтересовпротивоположных классов, социальных групп; каждая функциональная форма собственности отражает определенный уровень развития производительной силы труда человека; развитие сущностной основы отношений собственности происходит эволюционным путем, а изменение правовой формы собственности - институциональными инструментами; институциональные формы собственности сочетают в себе как отжившие формы, таки только что рожденные; каждому типу цивилизации присущ специфический для условий ее развития доминирующий объект собственности, отражающий достигнутый уровень развития производительной силы труда человека и соответствующие формационные особенности присвоения средств и результатов производства и т. д. 